\title{
Chapter 8 \\ Women in Computing and the Contingency of Informatics Cultures
}

\author{
Britta Schinzel
}

\begin{abstract}
The paper first shows how early programming was highly shaped by women, and who these were. It further shows when and why computing moved into the hands of men. Then it will deal with the culturally most differentiated participation of women in informatics studies. It turns out that low female participation is mainly a problem of the western, and north-western countries in the world. A lot of reasons are given, also only suspected ones, but there are so many diversities and influences, both in space and in time, that it is difficult to put them together into a consistent and stable picture. This also makes strategies to invite more women into (western) computing a contingent task and it requires steady accompanying measures.
\end{abstract}

\subsection{Introduction}

Not only Ada, countess of Lovelace marked the history of computing, but also many female mathematicians from the beginning of the twentieth century until its third quarter. Female participation in informatics broke down mid of the 1980s with the introduction of home-computers and PCs, i.e. with the quick growth of economic importance of software. Its gradual decline in Western countries contrasts with the high, equal or even higher participation of women in southern and eastern countries. With more foreign students in the western countries also the number of women in computing here has risen is still rising.

\footnotetext{
B. Schinzel (ه)

University of Freiburg, Freiburg, Germany

e-mail: schinzel@modell.iig.uni-freiburg.de 


\subsection{Women in the History of Computing}

The first people, who set the pace for computing programmable machines were women. It began already in the nineteenth century with Ada, Countess of Lovelace, who described the functioning of Charles Babbage's Analytical Engine, which although mechanical, already had the structure and concepts of the von Neumann computer. She also worked out several programs for computing analytical functions, as well as his program for computing the Bernoulli numbers, where she developed many structuring principles, reinvented also later.

Less well known are the early twentieth century women starting already before world war II with numeric computing and taylorizing computing work, and continuing into electric and electronic computing, like Gertrude Blanch, Mina Rees, the genial mathematician Ida Rhodes or Thelma Estrin. ${ }^{1}$ They were mostly mathematicians coming from Eastern Europe to the US, having fled antisemitism and prosecution against Jews in Ukraine and Poland. They all worked for the national bureau of standards (NBS) and directed the transfer from hand driven computing machines to the modern Computer era. They established groups of "computers", by this already delivering a structural model for electronic machines. The term "computers" stood for female mathematicians taylorizing computing tasks and setting up, i.e. wiring programs on hardware. With Mark I, the first computer used for world war II flight curves of rockets were computed and the effects of the first plutonium bomb were simulated. And it was Grace Murray Hopper, also the first female admiral in the US forces, who led the programming of Mark I. She designed COBOL, wanted it to be an understandable programming language, and she developed the first Compiler for it. The term "bugs" stems from her. Also in England women worked for the decryption of the German code in Bletchley park.

Another pioneer women connected with warfare was Hedy Lamar She was a Viennese actress, in the film "ecstasy" she had the first naked take. In 1937 she fled her husband Fritz Mandl, who was a weapon producer, because she could not stand his jealousy, and went to the US. She was considered as the most beautiful woman in the world. The following citation is known: "Any girl can be glamorous. All you have to do is stand still and look stupid". She also worked with film music together with Georges Antheil, and with him she developed the frequency hopping for synchronizing 16 mechanical pianos driven by punched cards. During world war II she wanted to fight the Germans - she was Jewish, and from her knowledge about telegraphy, which she knew from her husband, she used this technique for steering torpedos, which could not be tracked. This method today is used for every communication between mobiles, radio communication, bluetooth, mobile internet, etc., in order to make it secure. They had a patent for it, but the US military at that time did not use it.

In the 1950s programming languages were mainly developed by women: Grace Hopper with COBOL, Jean Sammet with FORTRAN_-she also wrote the first book

${ }^{1}$ http://www.frauen-informatik-geschichte.de 
on programming languages. Later Adele Goldberg together with Alan Kay developed Smalltalk, which still is considered an excellent programming language, anticipating object orientation. Women were again deeply engaged in the norming processes. Whereas hardware development was a male task, programming, less respected, was a female one, as Alan Turing said, "something for girls" (Hellige 2014). Even in the 1960s programming was done by a high percentage of women, and when Computer Science (CS) started as a scientific subject and course of studies in the end of the 1960s still a quarter of the students beginning to study CS were female. As software and IT became important economic and social factors with the introduction of PCs in households mid of the 1980s programming and software development went from female into male hands - and at that time female participation dropped considerably.

Also female theoreticians prevailed and still do so, finding a way from mathematics to informatics, with the motivation of a real world application: for example Rosza Péter from Prague worked in classifying primitive recursive functions. But also a different track of interest more frequently attracting women leads from applications and human-computer interaction to informatics: e.g. Brenda Laurel is well known having lifted interface design to scientific investigation.

\subsection{The Contingent Female Enrollment in Informatics Studies}

As already mentioned, until the end of 1960s programming was a female task. With the beginning of Computer Science as a scientific discipline in the end of the 1960s or the beginning of the 1970s, where engineers and mathematicians found together, this changed. But still there were many women in CS courses, in Germany around $25 \%$. With introduction of home computers mid of the 1980s, with the movement from mainframes to personal computers, and the increase of applications, software became more important. With this came the breakdown of the female fraction in computing: not only in Germany the figures gradually dropped to $13 \%$ and later even lower (Camp 1997, 2001). Observing this change, in the 1980s I started to collect figures of informatics student's and also scientists and professors numbers, wherever I could find them. It was not an easy task and also sometimes a very costly one. Often I had to rely on particular figures of single universities given by colleagues I got to know, especially in countries whose writings I could not read, like Iran, Iraque, Syria or Egypt.

The numbers of scientists in technology and informatics differ according to different countries and cultures, but in particular also the numbers of students. The low versus high enrollment differences in all the levels of scientific employment or education appear between north and south, west and east, rich and poor, industrially developed and developing countries. Differences occur between South Asian and South American countries on the one hand, and Australia, New Zealand, Japan, 
Northern Europe and the USA on the other one. Low female participation is in fact a western problem, not an eastern or southern one, nor an Arabic or Iranian (A countries) or Islamic problem, even not a Saudi Arabian. Both the decline of the Soviet Union and the breakdown of structures in the Arabic countries were catastrophic for female participation. But the differences also appear within Europe (Schinzel 2004a). Within the European Latin countries and in Greece and Turkey (called L in the following) as well as in the Slavic countries and Romania (called S in the following) the situation was (and mostly is) completely different to the one in the Anglo-Saxon, Scandinavian and German speaking countries (called ASG in the following): in L countries there was a comparatively high and constant female participation in computer science, which amounted up to 50\%-it gradually sinks in the present (Schinzel 2004a). In S countries as well as East Germany (GDR) the f. p. before the fall of the iron curtain partially has reached far above $50 \%$, but has declined thereafter. In GDR in the 1960s and 1970s sometimes there even were over $70 \%$ women both as beginners and as graduates (Schinzel 2004b). In this time the streams of students were directed according to the needs of the work market, i.e. it was possible to articulate ones wishes, but there was no guarantee to follow them, a free choice of the course of studies was not possible. But later in the 1980s there already existed free choice of ones preferred course of studies, and still the participation of women was high (Schinzel 2005a) (Figs. 8.1 and 8.2).

With the reunion of Germany the situation changed drastically at all places in GDR, the most striking one shown in the figure of the TU Rostock (Fig. 8.3).

Also at the University of Chemnitz a considerable decline of f.p. occurred, even if more retarded. The following figure, which shows the numbers of successful diploma students in Chemnitz (having begun their course of studies still in GDR

\section{Women in Computer Science (Informationsverarbeitung) in the former GDR}

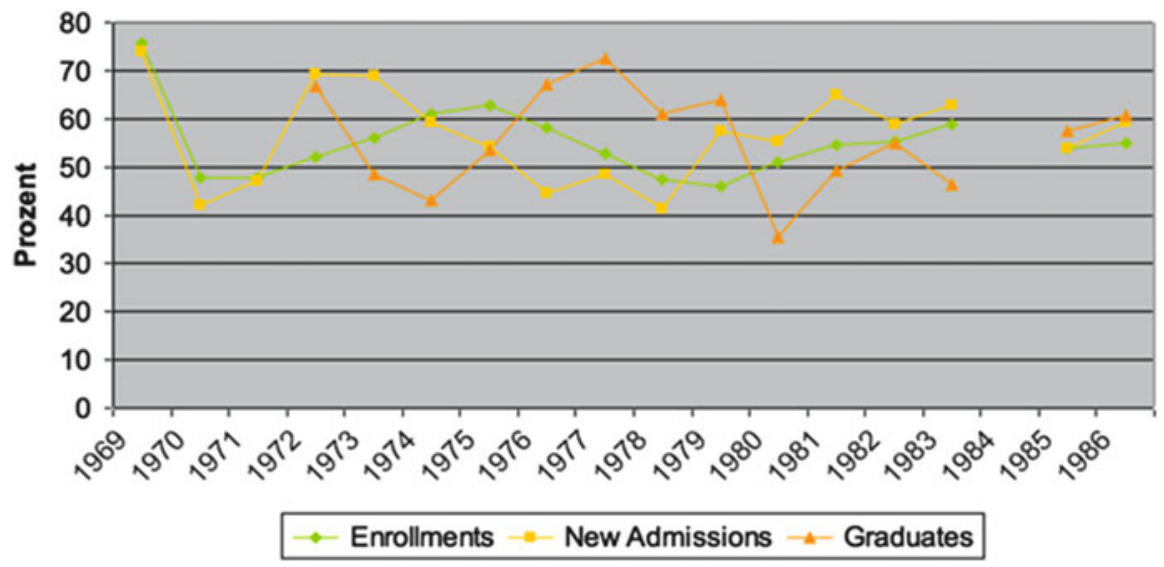

Fig. 8.1 Women in computer science GDR (Source: Dolores L. Augustine, private communication; diagram B. Schinzel) 


\section{Effects of the reunion of Germany on the female enrollment in Computer Science at the Technical University of Rostock}

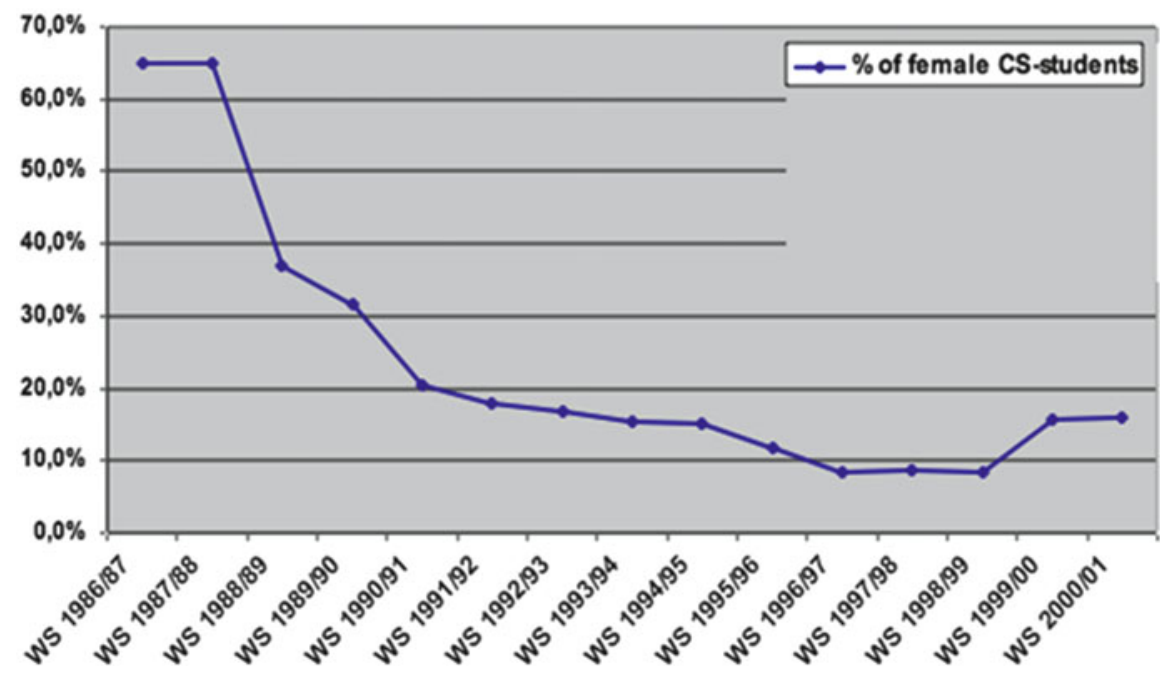

Fig. 8.2 Effects of the German Reunion (Source: Private communication with the Studien- und Prüfungsamt of the Technical University of Rostock, 2002)

Female Students enrolled in their first semestre in Computer Science (Informatik) at the Technical University Chemnitz 1984-1998

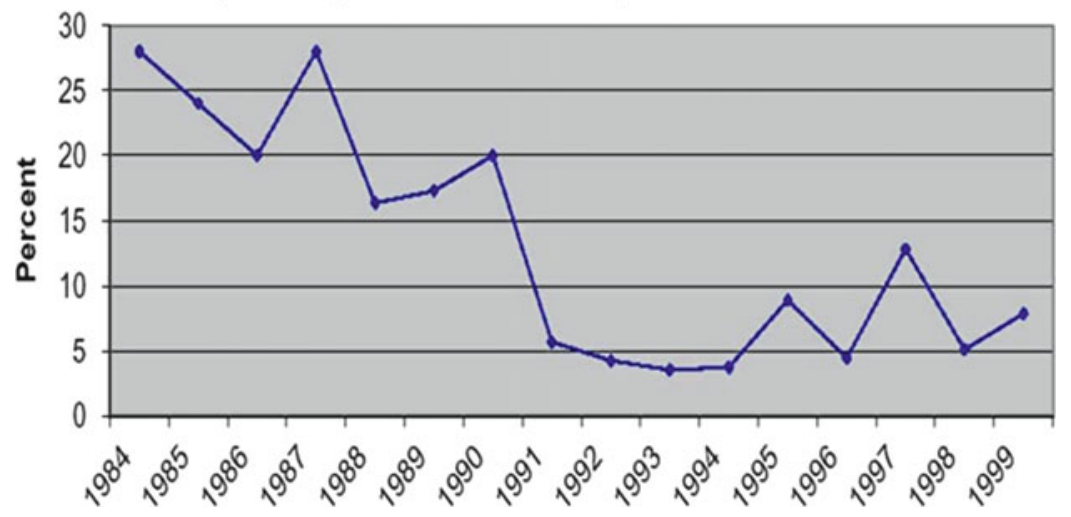

Fig. 8.3 University Chemnitz, female students. Source: Private communication with the Studenten- und Prüfungsamt of the Fachbereich Informatik of the Technical University of Chemnitz, 12.02.2002

times) also shows that the lower participation does not only rest on the female decline, but is also due to the rise of the number of male students (Fig. 8.4).

Through personal communication I heard from Hungarian and Czech colleagues considerable declines in f.p. after the democratic and economic changes. The reunion of Germany has brought a heavy break of f.p. within the former East German countries. 


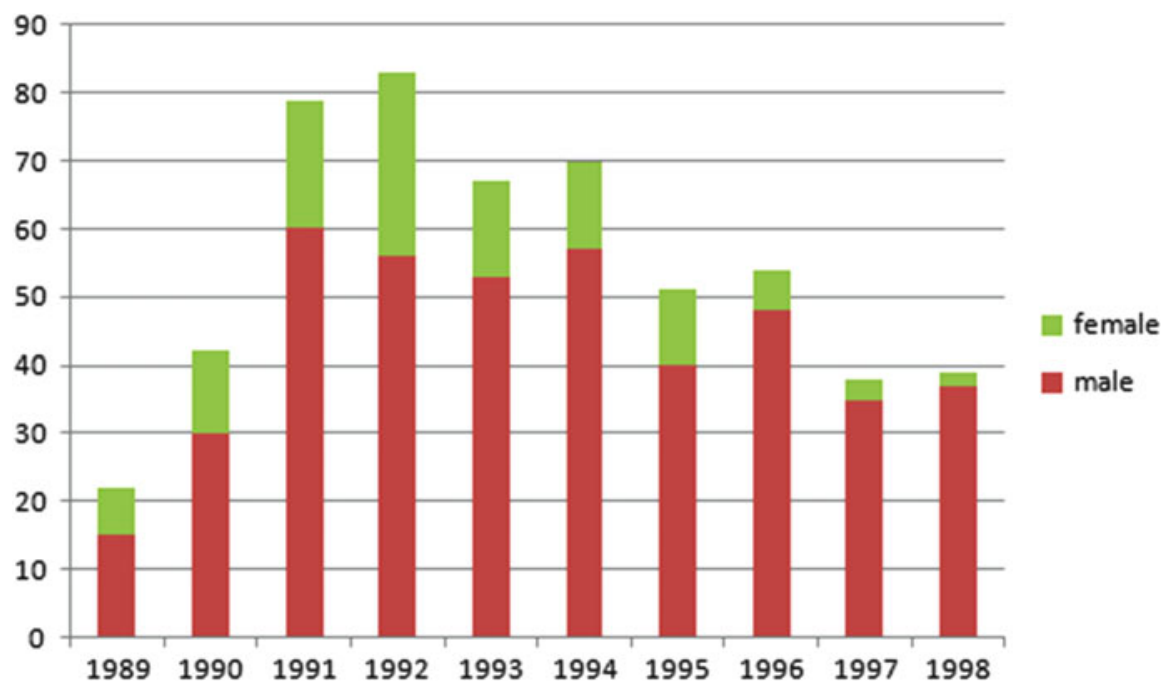

Fig. 8.4 University Chemnitz, Diploma students female students

Also within reunited Germany we can see the higher numbers of foreign female students (Figs. 8.5 and 8.6).

Also in Switzerland there are considerable differences between the German and the French speaking universities, this especially in business computing (Betriebsinformatik). But the language there is also the difference of religious traditions, that catholic French and Italian speaking Swiss and the protestant German speaking Swiss population (Table 8.1).

The actual figures 2014 in Germany show a much higher percentage of women in informatics with $29.9 \%$. At the same time the female graduates in informatics range by $16.8 \%$, and together with mathematics by $27.1 \%$. (Statistisches Bundesamt 2002 and 2005, drafted 2015) The fact that the fraction (and absolute number: 9033) of female students is double as high as the fraction (and absolute number: 3809) of female graduates supports the suspect that this difference is due to the strongly rising number of foreign students with their higher female participation. $^{2}$

\subsection{Understanding the Findings}

There are a lot of different and context dependent explanations for such differences, among which structural and historic reasons, as well as socio-cultural and symbolic constructions of the gender technology relation are prevalent (Schinzel 2005a, b).

\footnotetext{
${ }^{2}$ Unfortunately I have no access to the actual numbers of foreign informatics students.
} 


\section{Foreign Computer Science Students}

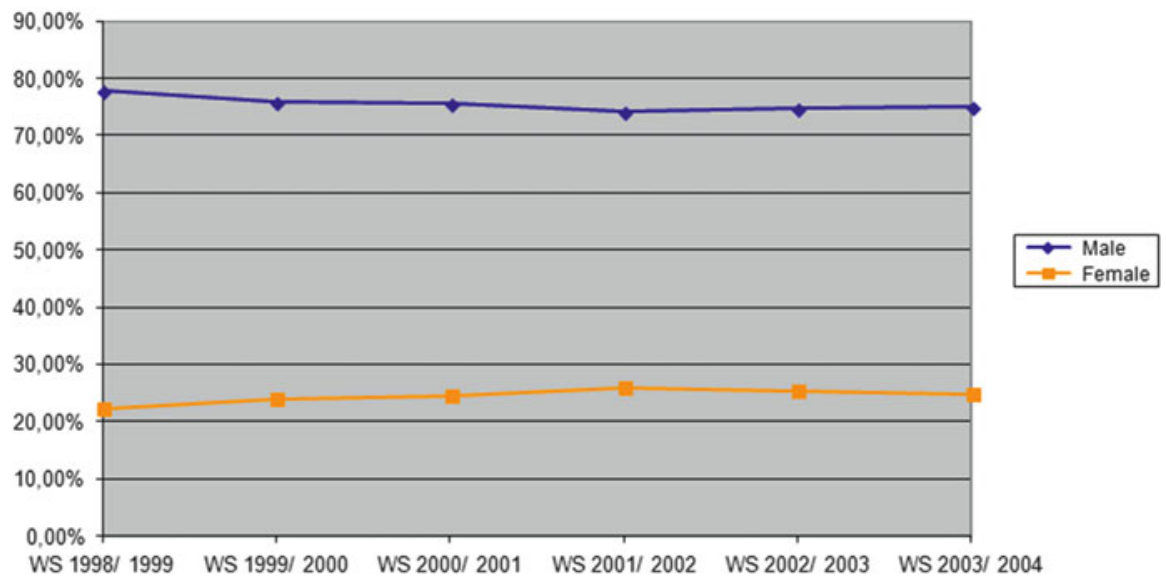

Fig. 8.5 Foreign computer science students (Source: Statistisches Bundesamt 2002)

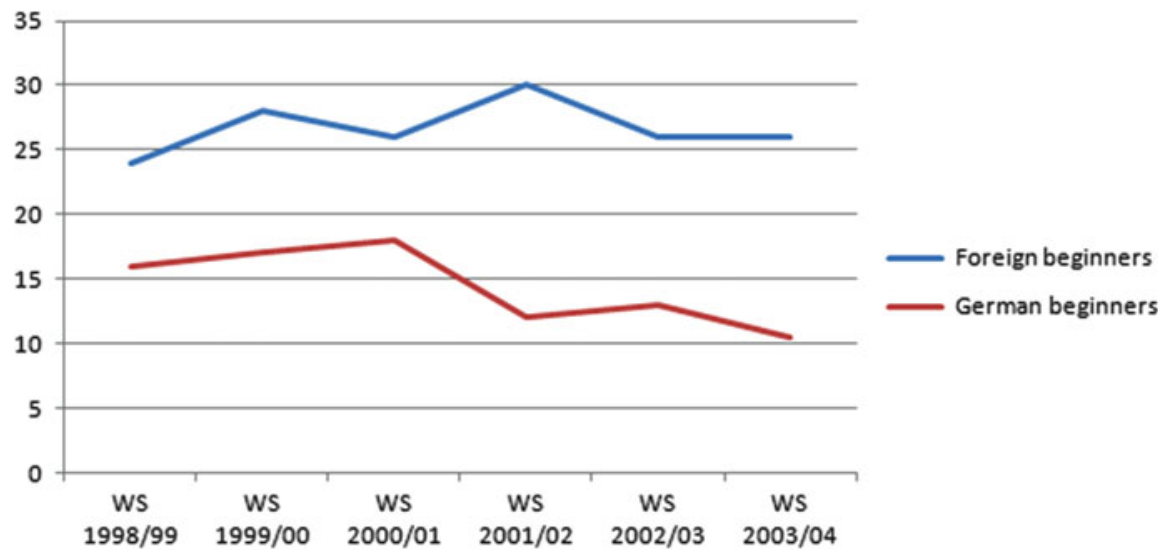

Fig. 8.6 Computer science beginners as \% of total number of CS students (w.r.t. to German and foreign students) (Source: Statistisches Bundesamt 2005)

The near equal or higher participation of women in CS studies within the developmental and the third world countries usually is explained by the fact that only the upper class there can study at all. Especially in South America the women stemming from rich families can afford to let their household and child care be run by house personnel. It might be easier in India, Malaysia, Korea and other Asian countries as well to have cheap help for housework. Still this does not suffice as explanation, it must also be the case that in these countries gender hierarchy is not performed on the level of attribution of skills in technology and mathematics. High validation, power and income always corresponds with maleness of a profession, a fact called the vertical gender hierarchical job market. The vertical gender specific 
Table 8.1 Language differences also in Switzerland

\begin{tabular}{l|l|l|l|l}
\hline & 1991 & 2001 & \\
\hline Studies & Students & Female \% & Students & Female \% \\
\hline $\begin{array}{l}\text { Computer Science } \\
\text { German Switzerland }\end{array}$ & 1074 & 4.8 & 1413 & 11.5 \\
\hline Western Switzerland & 664 & 11.9 & 1099 & 13.3 \\
\hline Total & 1738 & 7.5 & 2512 & 12.3 \\
\hline Business Informatics & 332 & 6.6 & 1025 & 13.9 \\
\hline German Switzerland & 272 & 22.8 & 390 & 24.1 \\
\hline Western Switzerland & 604 & 13.9 & 1415 & 16.7 \\
\hline Total &
\end{tabular}

Source: BfS, Sektion Hochschulen und Wissenschaft; computation Dupuis et al. (2003)

job market contingently influences the horizontal gender specific job market, which tells, which kind of professions are gendered, e.g. social work, teaching, nursing is female and e.g. engineering and science are male. Whereas the vertical gendering is invariant in all patriarchal societies, the horizontal one is contingent according to the specific economic and social structures.

In the former Soviet Union, when mathematics was a breadless art, in Riga 1983 I found $95 \%$ of the students female, and also medicine was and still is female, but Physics and Chemistry were male subjects due to the higher respect, income and career possibilities. But for the former socialist countries again another explanation for the former high representation of women in engineering (it has declined considerably everywhere there after the economic changes) is ready to hand. Not only the communist claim of their equal treatment of women and men, and the social and ideological enforcement of women's working on the job market, had and still has large influence. For the participation in science and technology the specific education with polytechnic courses probably played and plays far greater a role. Every pupil has to attend several years of these courses implying working in industrial firms, thereby getting familiar with working in industrial, i.e. technological contexts. This makes the entrance to technological work and study for women more a matter of course. In reunioned Germany it is still very visible, how much more self confident former East German women in informatics and engineering are than former west German ones.

Also the educational structures give reasons for differentiation of gender participation. In countries where access to university subjects is directed by exams, as e.g. in A or $\mathrm{S}$ countries, as known e.g. from former Egypt or Bulgaria, ${ }^{3}$ the better performance of women in respective exams leads them into techno-scientific studies. Why then are women performing better there, also in MINT subjects?

\footnotetext{
${ }^{3}$ In Bulgaria after the fall of the Iron curtain a quota of $50 \%$ for men was introduced, such that the access grades for men became lower than the ones for women. The same procedure is considered today in Iran because the number of women studying exceeds the one of men.
} 
Can it be explained by the assumption that girls and young women rest more in the house than boys and therefore have more time to learn?

Another reason for difference may be the role of universities between education and research, which differs throughout the various countries. As education is considered more female this might have an effect on gendering the participation in university studies in general. Usually the fact that for instance in Turkish universities $40 \%$ of the staff is female, and that Turkey within Europe, the former socialist countries excluded, shows the highest participation of women in natural sciences and technology, is explained by the more educational role of universities there. As in the Arabic the educational aspect dominates, and with it points into a female domain in the North West the emphasis of universities is laid on research and competition.

Another aspect is the symbolic meaning of computing. In Asia and within the Arabic countries it is connected with bureau and organizational work, whereas in the US and ASG with "high tech" it is marked as technological front end, attributed as a men's domain. An Iranian female student told me, that computing is an excellent profession for women, because it can be performed in cool, quiet and safe rooms, and this attribution was confirmed by a female Iraqui colleague.

Whereas structural causes can explain the differences between the former Soviet countries and ASG countries, as well as between the third world and ASG countries, the USA etc., the difference between L countries and ASG countries seems to be caused by historic and cultural reasons. It cannot have its grounds in differences of political systems nor in the developmental state (if considering for example France and Italy). In the north-west of Europe industrialization started end of the eighteenth century with the weaving machines, steam engines and electrification, causing the labour division between home and public sphere and with it the gendering of workplace and competence. The later beginning of industrialization in southern and south-eastern Europe already met different, less distant symbolic gender-technology relations. But even earlier it is possible to refer to the symbolic gender division from enlightenment of male rationality versus female empathy and morality. It is clear that in a country which founded the Royal Society, the first scientific institution in the world, science and all the connotations which Frances Bacon put on its male values plays a greater role than in others. It may be argued that the older the institutionalization of science the more conservative paradigms remain in these institutions. But what about France and the academie francaise, the second scientific institution in the world? Renee Descartes, the founder had less definitive imaginations about the maleness of science than Bacon did. And in fact in France we find famous female scientists like Madame Curie and her daughter since a long time, and they are much more adored than comparably outstanding female scientists like Emmy Noether or Lise Meitner in Germany. German science still suffers from the consequences of the "Third Reich": during Hitler's time only 10\% of all students were allowed to be female. The role of woman was that of a breeding machine of the German race. Female intellectuals had been Jewish to a high percentage, and they do not exist anymore in Germany up to today. After the breakdown of Germany with the establishment of a new democracy the education of children was willingly put into the hand of family in order to avoid comparable 
indoctrination of children as it was done in Hitler's time. Therefore no whole day schools and few kindergartens were established, and most of the Kitas of former GDR were closed for the same reason after 1989. Today this appears as a problem for women's participation on the job market, but a (re)establishment of public child care is difficult. The German tax and income system still heavily supports women staying at home and not working.

Also a sociological interpretation can help to find explanations. It claims that with the dissolving of gender differences in law and other institutionalized forms a particularization of gender roles has appeared, i.e. societies seem to keep up differences informally. This implies that the uphold of gender hierarchy seems to be of urgent social desire. As up to short time ago the gender difference was institutionally guaranteed, today it has to be created by action and this also has to be marked symbolically. This makes gender differences context dependent, and its creation to a process with many prerequisites bound to specific constellations. As a consequence in certain contexts gender differences can be dissolved whereas in other ones they can be kept up or even strengthened. Heintz, B. and Nadai E show how this influences gendering in different professions, in informatics, nursing and in office work (Heintz and Nadai 1998). This obviously can explain the gendering of new technologies and the horizontal gendered workforce in general, and especially the male gendering of informatics in ASF countries.

Why then is informatics less or not gendered in France, Italy, Russia, etc.? I would like to extend the argument also to the dissolving of cultural gender differences. Both in the European Latin and in the Slavic countries there exist more specified gender cultures, which allow the individuals of both sexes self conscious gender identities. These cultures are performed mostly in the interaction between men and women and among the two sexes off workplace. These groups confirm their members in their self esteem as women or men. In Italy e.g. I think of very distinctive and self confident gender cultures, not only concerning the role of mothers, but also in youth with dressing and playing the games between the sexes. In Russia I think of the common conviction of women and men, that men are incapable of organizing everyday life, giving women a fairly self conscious gender identity. Therefore in these countries a self respect stemming from being a woman as well as from being a man as such is kept up. So there is no necessity for boys or men to hold their ground nor to compete with women intellectually. Therefore women easier can consider themselves as of equal mental power, also in subjects like informatics. And boys and men need not take up the computer in order to stabilize their male identity. In fact speaking to Italian teachers they report that considering informatics as male subject or the computer as male tool would be considered as absurd in Italian schools. The borders between maleness and femaleness are well defined by a gender culture. Such gender cultures in general do not exist in our countries any more. Women are not proud of their gender here and girls gradually are losing convictions of their value in school.

I suppose that it may also explain the contingencies of participation of women in technology and sciences throughout the different European countries. In the Roman languages speaking countries the defined culture of genders also implies a self- 
confident identification with ones own sex both of females and of males, making it less necessary to create gender differences by definition of gendered competence.

Within the ASG countries the interaction between men and women is gendered more by hierarchy. But the making of hierarchies has to be grounded in competence and performance. Boys in mixed schools find it difficult to uphold their superiority, when observing the performance of girls, because of the obvious appearance of contrary experiences, a fact, which makes them aggressive and violent against girls. A way out is to usurp subjects as male ones, like computer science, science and technology. In fact this is what happens in Germany: Boys displace girls from the computer or put them into an assistants position. Boys claim computers and programming for themselves, since their breakthrough and high economic and social value has appeared. So what happens is the gendering of highly respected subjects, like computing, because the definition of gender identity is left much more to contingency and to the individual. As a consequence of the gendering of competence, i.e. leaving the low estimated competence to women, self-confidence of women as such is heavily reduced. The role of woman as housewife and as bewarer of ethics and culture has lost its value, the role of women on the job market is defined by gender-hierarchy, and both end up in a permanent struggle with both heavy working load and low self-esteem.

Although gender as a factor of ordering society looses its importance in general, it shows considerable persistence in many areas, and even gains importance on the symbolic level for ordering of subjects. So again a contextualisation of gender difference takes place, this time one of consideration of competence, which creates symbolic gendering of subjects, aimed to creation of borders between the genders and a social closure for women. If so, unfortunately this statement does not give rise to a politics of dissolving cultured gender differences in general, making deconstructive work questionable as well. At least such a program should imply also flanking provisions concerning the change of patriarchal identities. Else the free space opened up after deconstruction might not be used in the sense of creating an identity which includes equal value and equal rights to both sexes, but might shift an even heavier load of symbolic deconstruction on women's shoulders.

As software like every technology is value loaded, it is relevant, who is shaping it, because later on the values baked into software is shaping us, the whole society. As software and the Internet is heavily dominated by the US and an English speaking culture, there is a heavy danger of implementing this gendered culture of computing onto the whole world.

\section{References}

Augustine DL (1999) The "Socialist Silicon Ceiling": East German women in computer science. In: Brown A, Morton D (eds) Proceedings of the 1999 international symposium on technology and society: women and technology: historical, societal, and professional perspectives, Rutgers University, New Brunswick, IEEE Catalog No. 99CH37005, ISBN 0-7803-5617-9, pp 347-356 
Camp T (1997) The incredible shrinking pipeline. Commun ACM 40(10):103-110

Camp T (2001) The incredible shrinking pipeline. Commun ACM 44:108-114

Dupuis M, Liebig B, Pietro M (2003) Informatik in der Schweiz: Ausbildung, Beschäftigung, Markt (1981-2001). Eine Bestandesaufnahme unter besonderer Berücksichtigung geschlechtsspezifischer Segregation. http://www.bbt.admin.ch/berufsbi/grund/feld/informatik/d/markt.htm

Heintz B, Nadai E (1998) Geschlecht und Kontext. De-Institutionalisierungspro-zesse und geschlechtliche Differenzierung. Z Soziol 27(2):75-93

Hellige H-D (2014) Die Informatisierung der Lebenswelt. Der Strategiewandel algorithmischer Alltagsbewältigung, artec-paper Nr. 196, Februar 2014, ISSN 1613-4907

Schinzel B (2004a) http://mod.iig.uni-freiburg.de/cms/fileadmin/publikationen/online-publikationen/ Frauenanteil.Informatik.International.pdf

Schinzel B (2004b) http://mod.iig.uni-freiburg.de/cms/fileadmin/publikationen/online-publikationen/ Informatik.Frauen.Deutschland.pdf

Schinzel B (2005a) http://mod.iig.uni-freiburg.de/cms/fileadmin/publikationen/online-publikationen/ Frauenbeteiligung.Informatikstudien.pdf

Schinzel B (2005b) http://mod.iig.uni-freiburg.de/cms/fileadmin/publikationen/online-publikationen/ Informatik.Kultur.Literatur1.pdf

Statistisches Bundesamt Fachserie (2015) 11, reihe 4.3.1 Bildung und Kultur, Nichtmonetäre hochschulstatistische Kennzahlen, 1980-2014, Wiesbaden

Open Access This chapter is licensed under the terms of the Creative Commons AttributionNonCommercial 4.0 International License (http://creativecommons.org/licenses/by-nc/4.0/), which permits any noncommercial use, sharing, adaptation, distribution and reproduction in any medium or format, as long as you give appropriate credit to the original author(s) and the source, provide a link to the Creative Commons license and indicate if changes were made.

The images or other third party material in this chapter are included in the chapter's Creative Commons license, unless indicated otherwise in a credit line to the material. If material is not included in the chapter's Creative Commons license and your intended use is not permitted by statutory regulation or exceeds the permitted use, you will need to obtain permission directly from the copyright holder.

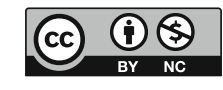

